\title{
Tumor Endothelial Cells Acquire Drug Resistance by MDR1 Up-Regulation via VEGF Signaling in Tumor Microenvironment
}

\author{
Kosuke Akiyama, ${ }^{\star \dagger}$ Noritaka Ohga, ${ }^{*}$ \\ Yasuhiro Hida, ${ }^{\ddagger}$ Taisuke Kawamoto, ${ }^{*}$ \\ Yoshihiro Sadamoto, ${ }^{*}$ Shuhei Ishikawa, ${ }^{*}$ \\ Nako Maishi, ${ }^{*}$ Tomoshige Akino, ${ }^{* \S}$ \\ Miyako Kondoh, ${ }^{*}$ Aya Matsuda, ${ }^{\text {" }}$ Nobuo Inoue, ${ }^{\dagger}$ \\ Masanobu Shindoh, ${ }^{\text {ๆ }}$ and Kyoko Hida*

\begin{abstract}
From the Departments of Vascular Biology,* Gerodontology, ${ }^{\dagger}$ and Oral Pathology and Biology," Graduate School of Dental Medicine, and the Departments of Surgical Oncology $y^{\ddagger}$ and Renal and Genitourinary Surgery, Graduate School of Medicine, University of Hokkaido, Hokkaido, Japan
\end{abstract}

Tumor endothelial cells (TECs) are therapeutic targets in anti-angiogenic therapy. Contrary to the traditional assumption, TECs can be genetically abnormal and might also acquire drug resistance. In this study, mouse TECs and normal ECs were isolated to investigate the drug resistance of TECs and the mechanism by which it is acquired. TECs were more resistant to paclitaxel with the up-regulation of multidrug resistance (MDR) 1 mRNA, which encodes the P-glycoprotein, compared with normal ECs. Normal human microvascular ECs were cultured in tumor-conditioned medium (CM) and became more resistant to paclitaxel through MDR1 mRNA up-regulation and nuclear translocation of Y-box-binding protein 1, which is an MDR1 transcription factor. Vascular endothelial growth factor (VEGF) receptor 2 (VEGFR2) and Akt were activated in human microvascular ECs by tumor $\mathrm{CM}$. We observed that tumor $\mathrm{CM}$ contained a significantly high level of VEGF. A VEGFR kinase inhibitor, Ki8751, and a phosphatidylinositol 3-kinase-Akt inhibitor, LY294002, blocked tumor CM-induced MDR1 up-regulation. MDR1 up-regulation, via the VEGF-VEGFR pathway in the tumor microenvironment, is one of the mechanisms of drug resistance acquired by TECs. We observed that VEGF secreted from tumors up-regulated MDR1 through the activation of VEGFR2 and Akt. This process is a novel mechanism of the acquisition of drug resistance by TECs in the tumor microenvironment. (Am J Pathol 2012, 180: 1283-1293; DOI: 10.1016/j.ajpath.2011.11.029)
Tumor angiogenesis is necessary for solid tumor progression and metastasis. ${ }^{1}$ Tumor blood vessels promote tumor progression by providing nutrition and oxygen ${ }^{2}$ and also function as metastasis gatekeepers for tumor cells. $^{2}$ In addition, tumor endothelial cells (TECs) are genetically stable and do not acquire drug resistance. ${ }^{3,4}$ Therefore, inhibition of tumor angiogenesis is an attractive strategy for cancer treatment.

Low-dose anti-angiogenic or metronomic chemotherapy has been developed to target tumor angiogenesis. 5,6 Adjuvant chemotherapy with uracil-tegafur, which is considered a form of metronomic chemotherapy, improves survival among patients with completely resected pathological stage I lung adenocarcinoma. ${ }^{7}$ Furthermore, lowdose metronomic paclitaxel has been proposed for use in breast cancer treatment. ${ }^{8}$ The theoretical advantage of targeting ECs instead of tumor cells is that, unlike tumor cells, ECs are genetically stable and do not develop drug resistance. ${ }^{3,4}$

However, such therapeutic treatments lose their effect over time, possibly because of drug resistance caused by the compensatory response of tumor cells. Long-term suppression of the expression of one angiogenic protein can lead to the emergence of the expression of other angiogenic proteins. Another reason might be the acquisition of drug resistance by ECs. Several studies have reported that tumor blood vessels differ from their normal counterparts with respect to changes in morphological characteristics, ${ }^{9}$ such as altered blood flow, enhanced leakiness, ${ }^{10}$ structural abnormalities in the basement membrane, and abnormal pericytes. ${ }^{11}$ Recent studies $^{12-14}$ have reported differences between TECs and

Supported by Grants-in-Aid for Scientific Research from the Ministry of Education, Science, and Culture of Japan (20390506 and 21659458 to K.H.) and the Akiyama Foundation (K.H.)

Accepted for publication November 17, 2011.

Supplemental material for this article can be found at http://ajp. amjpathol.org or at doi: 10.1016/j.ajpath.2011.11.029

Address reprint requests to Kyoko Hida, D.D.S., Ph.D., Department of Vascular Biology, Graduate School of Dental Medicine, University of Hokkaido, N13 W7, Kita-ku, Sapporo 060-8586, Hokkaido, Japan. E-mail: khida@ den.hokudai.ac.jp. 
normal ECs (NECs) at the molecular level. We have reported that TECs have several abnormalities, ${ }^{15,16}$ such as differences in responsiveness to growth factors [eg, epidermal growth factor (EGF), ${ }^{17}$ adrenomedullin, ${ }^{18}$ and vascular endothelial growth factor (VEGF) $]^{19}$ and to inhibitors (eg, epidermal growth factor receptor ${ }^{17}$ and epigallocatechin-3-gallate), ${ }^{20}$ compared with NECs. In addition, TECs have cytogenetic abnormalities, such as aneuploidy or abnormal centrosomes in mouse tumors ${ }^{15}$ and human renal carcinomas. ${ }^{21}$ Other studies ${ }^{22}$ have also reported cytogenetically abnormal TECs in malignant tumors, such as lymphoma. Because aneuploidy in TECs suggests the presence of genetic instability, the question arises whether TECs are drug resistant.

Some TECs are resistant to certain drugs. ${ }^{23-25}$ Renal carcinoma ECs are resistant to vincristine, ${ }^{23}$ whereas hepatocellular carcinoma ECs are resistant to 5-fluorouracil and doxorubicin (Adriamycin). ${ }^{25}$ However, the mechanism of drug resistance in TECs remains unknown. In the present study, we demonstrated that TECs are drug resistant and investigated the mechanism of acquisition of drug resistance. We treated human microvascular ECs (HMVECs), a type of NECs, with tumor-conditioned medium (CM) and analyzed changes in drug sensitivity and gene expression related to drug resistance.

\section{Materials and Methods}

\section{Cell Line and Culture Conditions}

HMVECs were obtained from Lonza (Tokyo, Japan) and cultured in endothelial cell growth medium for microvascular cells (EGM-2MV) (Lonza, Basel, Switzerland). A375SM cells (supermetastatic human melanoma cells) were kindly provided by Dr. Isaiah J. Fidler (M.D. Anderson Cancer Center, Houston, TX) and were cultured as previously described. ${ }^{26}$

\section{Antibodies}

The following antibodies were used: rat anti-mouse CD31 (eBioscience, San Diego, CA), fluorescein isothiocyanate (FITC)-Bandeiraea simplicifolia lectin isolectin B4 (BS1-B4; Vector Laboratories, Burlingame, CA), FITC-anti-mouse CD31, anti-mouse CD105, antimouse CD144 (BD Pharmingen, San Diego), APC-antimouse CD11b, APC-anti-mouse CD45 (Biolegend, San Diego), Alexa Fluor 488 goat anti-rat IgG, Alexa Fluor 594 goat anti-rabbit IgG (Invitrogen, Tokyo), anti-Ybox-binding protein 1 (YB-1), anti-phosphorylated Akt (Ser473), anti-pan-Akt (11E7), anti-VEGF receptor 2 (VEGFR2; 55B11), anti-phosphorylated VEGFR2 (Tyr 951; 15D2) (Cell Signaling Technology, Danvers, MA), MFP488 phalloidin (F-actin) (MoBiTec, Göttingen, Germany), anti-P-glycoprotein (P-gp; C219) (Abcam, Cambridge, UK), monoclonal anti- $\beta$-actin (AC-15; Sigma-Aldrich, St Louis, MO), anti-heterogeneous nuclear ribonucleoproteins (hnRNP) A1 (E-17; Santa Cruz Biotechnology, Santa Cruz, CA), and anti- $\beta$-tubulin (Millipore, Billerica, MA).

\section{Human Tissue Samples for Immunohistochemistry}

Tissues from two cases of renal tumor clinically diagnosed as renal cell carcinoma were surgically resected. All protocols were approved by the Institutional Ethics Committee, and written informed consent was obtained from each patient before surgery. Samples were surgically excised from the tumor tissues and from the corresponding normal renal tissues 5 to $10 \mathrm{~cm}$ from the tumor when possible. The samples were immediately snap frozen in liquid nitrogen and stored at $-80^{\circ} \mathrm{C}$ for immunohistological analysis. The final diagnosis of renal cell carcinoma was confirmed by pathological examination of formalin-fixed surgical specimens.

\section{Isolation of TECs and NECs}

TECs were isolated from melanoma xenografted in nude mice, and NECs were isolated from mouse dermis, as previously described. ${ }^{15,20,21,27}$ All animal experimentation procedures were approved by the local animal research authorities, and animal care was in accordance with the institutional guidelines. TECs and NECs were isolated using a magnetic activated cell sorting system (Miltenyi Biotec, Tokyo) with FITC-anti-CD31. CD31-positive cells were sorted and plated on $1.5 \%$ gelatin-coated culture plates and grown in EGM-2MV medium containing 15\% fetal bovine serum (FBS). Diphtheria toxin (DT; $500 \mathrm{ng} / \mathrm{mL}$; Calbiochem, San Diego) was added to the TEC subcultures to kill any remaining human tumor cells and to the NEC subcultures for technical consistency. ${ }^{15}$ Human cells express a heparin-binding EGF-like growth factor (HB-EGF), which is a DT receptor. ${ }^{28}$ However, murine ECs survive DT treatment because DT does not interact with mouse HB-EGF. Isolated ECs were purified with a second purification round using FITC-BS1B4. ${ }^{15,20,27}$ All experiments in this study were performed at three different times. Three experiments were performed to verify data reproducibility.

\section{Flow Cytometry}

TECs and NECs were incubated with FITC-BS1-B4, APCCD11b, APC-CD45, primary antibodies against CD31, CD105, and CD144, and Alexa Fluor 488 goat anti-rat IgG, as previously described, ${ }^{19,20}$ and analyzed by FACSAria II (Becton Dickinson, San Jose, CA).

\section{Tube Formation Assay}

Tube formation of ECs on Matrigel (BD Biosciences, San Jose, CA) was observed with an inverted microscope (CKX41; Olympus, Tokyo), as previously described. ${ }^{29}$

\section{Survival Assay}

Cells were plated in triplicate at a density of $2 \times 10^{3}$ cells for the proliferation assay and $5 \times 10^{3}$ cells for the survival assay in a 96-well plate containing EGM-2MV and 
were washed after 6 hours. The cells were incubated in EGM-2MV for the proliferation assay and were treated with paclitaxel (Taxol; Enzo Life Sciences, Plymouth Meeting, PA) for 72 hours in EGM2-MV or each CM containing paclitaxel at the indicated concentrations for the survival assay. Cell viability was analyzed using 3-(4,5-dimethylthiazol-2-yl)-5-(3-carboxymethoxyphenyl)2-(4-sulfophenyl)-2H-tetrazolium inner salt (MTS) assay (Promega, Tokyo).

\section{Cell Fractionation}

Cell fractionation was performed by separating cells into cytoplasmic and nuclear fractions, as previously described. ${ }^{29}$ The cells were harvested and resuspended in a fractionation buffer $[10 \mathrm{mmol} / \mathrm{L}$ Tris- $\mathrm{HCl}(\mathrm{pH} 7.6), 150$ $\mathrm{mmol} / \mathrm{L} \mathrm{NaCl}, 1.5 \mathrm{mmol} / \mathrm{L} \mathrm{MgCl}_{2}$, 0.5\% Nonidet P-40 (Sigma-Aldrich), and a protease inhibitor cocktail], followed by vigorous shaking for 5 minutes and centrifugation at $13,200 \times g$ for 30 seconds. The supernatant was used as the cytoplasmic fraction. The cell fractionation accuracy was confirmed by immunoblotting using cytoplasmic protein, $\beta$-tubulin, and nuclear protein, hnRNP.

\section{RT-PCR and Quantitative Real-Time RT-PCR}

Total RNA was extracted using the RNeasy Micro kit (Qiagen, Valencia, CA), and cDNA was synthesized using ReverTra-Plus (Toyobo, Osaka, Japan), as previously described. ${ }^{29}$ CDNA was amplified by PCR. PCR products were visualized by ethidium bromide staining and UV transillumination. Real-time RT-PCR was performed using SsoFast EvaGreen Supermix (Bio-Rad, Hercules, CA). Cycling conditions followed the manufacturer's instructions based on the use of CFX Manager (Bio-Rad). The relative expression levels were normalized to glyceraldehyde-3phosphate dehydrogenase. The following primers were used: mouse glyceraldehyde-3-phosphate dehydrogenase, 5'-TCTGACGTGCCGCCTGGAG-3' (forward) and 5'TCGCAGGAGACAACCTGGTC-3' (reverse); mouse multidrug resistance (MDR) 1, 5'-ATCCGGGAGCAGAAGTTTGA-3' (forward) and 5'-GCACCAAAGACAACAGCAGA-3' (reverse); VEGFR1, 5'-GAGGAGGATGAGGGTGTCTATAGGT-3' (forward) and 5'-GTGATCAGCTCCAGGTTTGACTT-3' (reverse); VEGFR2, 5'-GCCCTGCTGTGGTCTCACTAC-3' (forward) and 5'-CAAAGCATTGCCCATTCGAT-3' (reverse); CD11b, 5'-CCAAGAAAGTAGCAAGGAGTGTG-3' (forward) and 5'-AGGGTCTAAGCCAGGTCATAAG-3' (reverse); CD45, 5'-CCTCAAACTTCGACGGAGAG-3' (forward) and 5'-CACTTGCACCATCAGACACC-3' (reverse); human HB-EGF, 5'-CGGCCGGGACCGGAAA-3' (forward) and 5'-CCTGTTTGGTGTGG-3' (reverse); human glyceraldehyde-3-phosphate dehydrogenase, 5'-ACAGTCAGCCGCATCTTCTT-3' (forward) and 5'-GCCCAATACGACCAAATCC-3' (reverse); and human MDR1, 5'-GTGGGGCAAGTCAGTTCATT-3' (forward) and 5'-TCTTCACCTCCAGGCTCAGT-3' (reverse).

\section{Western Blot Analysis}

Cells were lysed as previously described. ${ }^{20,29}$ Total protein was measured using a BCA Protein Assay kit (Pierce, Rockford, IL). Western blot analysis was performed using antibodies specific to P-gp, YB-1, Akt, phosphorylated Akt, VEGFR2, phosphorylated VEGFR2, $\beta$-actin, and horseradish peroxidase-conjugated secondary antibody, as previously described. ${ }^{20}$ The cell fractionation accuracy was confirmed by immunoblotting using the cytoplasmic protein, $\beta$-tubulin, and the nuclear protein, hnRNP. ${ }^{29}$ P-gp and YB-1 levels were normalized to $\beta$-actin levels, and phosphorylated Akt was normalized to total Akt by scanning densitometry using ImageJ software version 1.43u (NIH, Bethesda, MD).

\section{Preparation of Tumor CM}

A375SM cells were grown to $70 \%$ to $80 \%$ confluency in minimal essential medium (MEM) with 10\% FBS (10\% MEM; culture medium for tumor cells). The culture medium was replaced with fresh medium, and the cells were incubated for 18 to 20 hours. CM was collected from these cells and passed through a $0.22-\mu \mathrm{m}$ filter (Millipore). HMVECs were exposed to fresh $\mathrm{CM}$, and the medium was changed after 2 days of the 5-day incubation period. HMVECs were also incubated for 18 to 20 hours in $10 \%$ MEM. HMVEC CM was collected in the same way as A375SM CM and was used as the control. HMVECs treated with control and tumor CM are indicated as HMVECs with control CM and HMVECs with tumor CM, respectively, in figures. CM containing 10\% FBS was replaced with CM without FBS to analyze cell apoptosis under serum starvation conditions.

\section{Cell Proliferation Assay}

After HMVECs were cultured in HMVEC CM and tumor $\mathrm{CM}$ for 5 days, $2 \times 10^{4}$ cells per well were seeded in a 24-well plate to analyze cell proliferation. The number of cells was counted after 48 hours. The experiment was repeated three times. Data are presented as the average of three well counts under the respective conditions.

\section{Flow Cytometry Analysis of Apoptotic-Necrotic Cell Death}

HMVECs were cultured under their respective conditions for 5 days, after which $1.5 \times 10^{5}$ cells per well were seeded in a six-well plate to analyze apoptotic-necrotic cell death. HMVECs were cultured in CM without FBS for 24 hours for the starvation assay. In addition, HMVECs were treated with paclitaxel and verapamil (Taiyo, Osaka) for 48 hours to test for drug resistance. The cells were stained with FITC-annexin $V$ and propidium iodide using the annexin V-FLUOS staining kit (Roche, Basel, Switzerland) and were analyzed by FACSAria II. 


\section{Immunocytochemistry}

The cells were cultured on coverslips under their respective conditions in a six-well plate, fixed in $4 \%$ paraformaldehyde for 10 minutes, washed with PBS for 5 minutes, and then permeabilized with Triton X-100 (Sigma-Aldrich). The cells were incubated with anti-YB-1 overnight at $4^{\circ} \mathrm{C}$, followed by incubation with secondary antibody and phalloidin (MoBiTec) at room temperature for 2 hours. Nuclei were stained with DAPI (Roche Diagnostics, Penzberg, Germany). Stained samples were visualized using a confocal microscope (FluoView FV1000; Olympus). The nuclear intensity ratio of YB-1 immunoreactivity in cells was quantified with ImageJ software. Quantitative analysis was performed using 30 separate images. Human samples were embedded in a cryocompound (Tissue-Tek; Miles, Elkhart, IN) and immediately immersed in liquid nitrogen. Frozen sections were double stained using Alexa Fluor 647-anti-CD31 and anti-P-gp and Alexa Fluor 594 goat anti-mouse IgG antibodies to reveal colocalization of CD31 and P-gp in ECs. All immunohistochemical samples were counterstained with DAPI.

\section{Heat Inactivation of Tumor CM}

Each $\mathrm{CM}$ was heated to $95^{\circ} \mathrm{C}$ for 60 minutes and then cooled to room temperature. HMVECs were incubated with control, tumor, or heat-treated CM for 1 day. RNA was then extracted, and the relative MDR1 mRNA expression levels under the respective conditions were analyzed by real-time RT-PCR.

\section{Determination of VEGF Using ELISA}

An enzyme-linked immunosorbent assay (ELISA) kit (R\&D Systems, Minneapolis, MN) was used to determine VEGF protein release, according to the manufacturer's instructions. CM was normalized by cell number per well.

\section{Kinase Inhibitor Assay}

HMVECs were pretreated with the indicated phosphatidylinositol 3-kinase (PI3K)-Akt kinase inhibitor, LY294002, or the VEGFR kinase inhibitor, Ki8751 (SigmaAldrich), for 2 hours. HMVECs were then treated with LY294002 or Ki8751 in each CM. HMVECs were treated
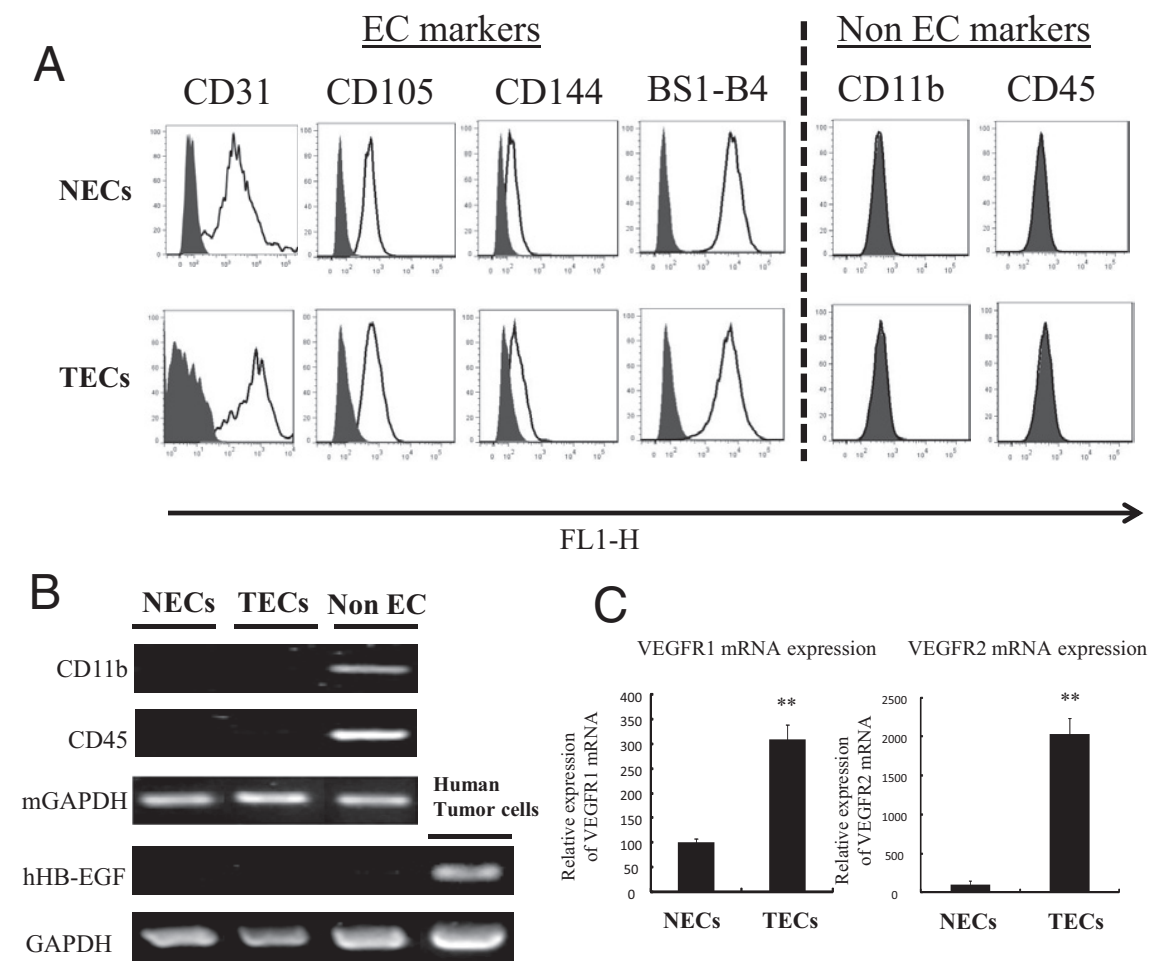

FL1-H

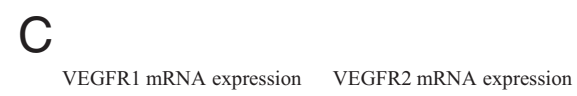

$\mathrm{D}$

NECs

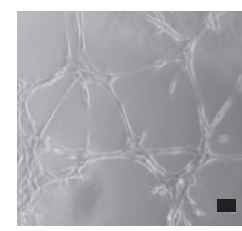

TECs

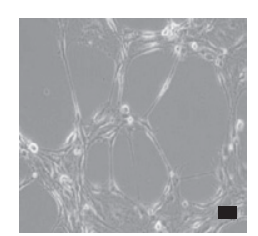

VEGFR1 mRNA expression VEGFR2 mRNA expression
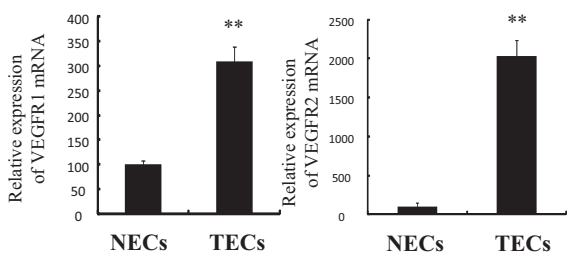

E

Cell Proliferation

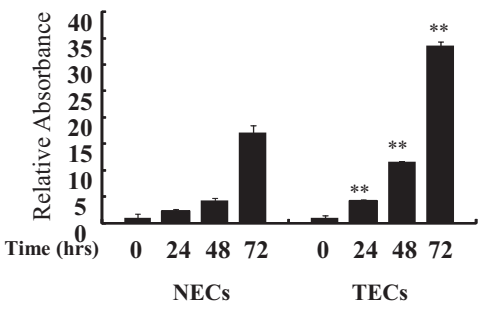

Figure 1. Characterization of NECs and TECs isolated from mice. A: Representative flow cytometric analysis of ECs showing white expression area of the endothelial markers CD31, CD105, CD144, and BS1-B4 lectin (mouse endothelial marker). The isotype control is shown in the black area. BS1-B4 lectin binding and CD31 CD105, and CD144 expression revealed the high purity of the isolated NECs and TECs by FACS. NECs and TECs were negative for non-EC markers, such as CD11b and CD45. B: All ECs were negative for the monocyte marker CD11b and the hematopoietic marker CD 45, unlike non-ECs (CD31-negative tumor stromal cells). Human HB-EGF, which is expressed by human tumor cells, was not expressed in TECs, indicating that TECs were not contaminated with human tumor cells. mGAPDH, mouse glyceraldehyde-3-phosphate dehydrogenase. C: The mRNA expression levels of VEGFR1 and VEGFR2 were higher in TECs than in NECs, as analyzed by real-time PCR. D: Isolated and cultured ECs formed tubes on Matrigel-coated plates. Scale bar $=50 \mu \mathrm{m}$. E: Proliferation of isolated and cultured ECs was determined by the MTS assay. TECs proliferated faster than NECs in 72 hours. ${ }^{* * *} P<0.01$. 
for 1 day to analyze the effect of LY294002 or Ki8751 on MDR1 mRNA expression and for 30 minutes to reveal VEGF signaling

\section{Statistical Analysis}

Differences between groups were evaluated using the Student's $t$-test. $P<0.05$ was considered significant, and $P<0.01$ was considered highly significant.

\section{Results \\ Isolation and Characterization of TECS and NECs}

Mouse TECs were isolated from human tumor xenografts grown s.c. in nude mice, and NECs were isolated from normal dermal tissue. TECs and NECs were characterized as previously described. ${ }^{15,20,27}$ TECs and NECs were observed to be positive for EC markers (CD31, CD105, CD144, and BS1-B4) and negative for the monocyte marker CD11b and the hematopoietic marker CD45 by fluorescence-activated cell sorter (FACS) analysis (Figure 1A). All ECs were observed to be negative for CD11b and CD45 by RT-PCR, indicating that they were highly purified ECs. We have demonstrated that TECs were purified without any contamination of tumor cells by using DT, which binds to human tumor cells expressing HB-EGF (a DT receptor ${ }^{28}$ ) but not to mouse cells. By using this method, we obtained TECs that were not contaminated with any human tumor cells (data not shown). Human HB-EGF, which is expressed by human tumor cells, was negative in TECs, indicating that they were not contaminated with human tumor cells (Figure 1B). VEGFR1 and VEGFR2 expression was analyzed by realtime PCR. TECs expressed higher levels of VEGFR1 and VEGFR2 compared with NECs (Figure 1C). Cultured ECs formed tubes on Matrigel-coated plates (Figure 1D). Furthermore, TECs proliferated faster than NECs $(P<0.01$, Figure 1E). High levels of VEGFRs might relate to high proliferation activity in TECs.

\section{TECs Are Resistant to Anticancer Drugs, MDR1/P-gp Is Up-Regulated, and YB-1 Accumulates in TEC Nuclei}

TEC and NEC responses to paclitaxel were compared to analyze sensitivity to the anticancer drug. TEC and NEC proliferation was inhibited by paclitaxel in a concentration-dependent manner after 72 hours. NECs were sensitive to paclitaxel (inhibitory concentration of $50 \%, 11$ $\mathrm{nmol} / \mathrm{L}$ ), whereas TECs were resistant to it (inhibitory concentration of $50 \%, 39 \mathrm{nmol} / \mathrm{L})(P<0.01$, Figure $2 \mathrm{~A})$. We measured the MDR1 mRNA expression levels and P-gp protein levels in TECs and NECs because the MDR1 gene and P-gp, the MDR1 gene product, are major drugresistance-related molecules and MDR1/P-gp is up-regulated in drug-resistant cells. The MDR1 mRNA expression level was approximately 2.2-fold higher in TECs than in NECs $(P<0.01$, Figure 2B). In addition, the P-gp

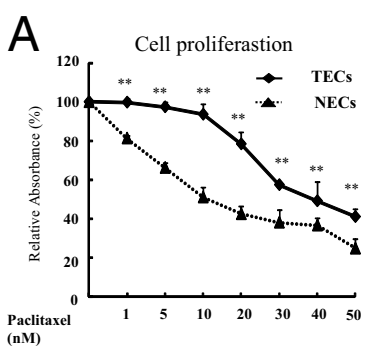

B MDR1 expression

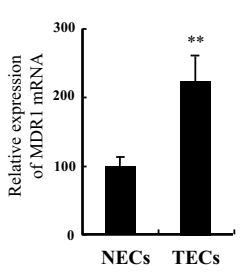

\section{P-gp expression

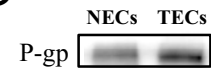 \\ $\mathrm{D}$}
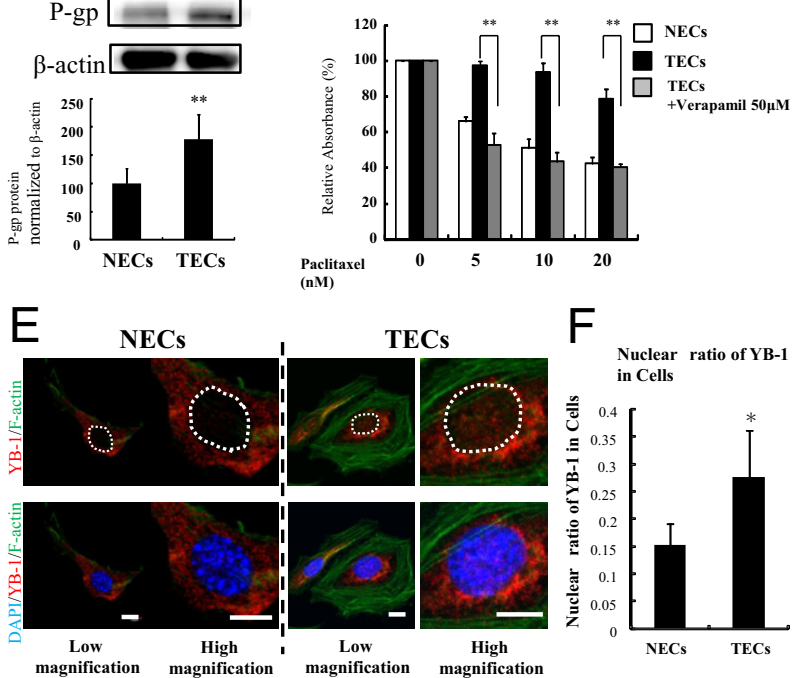

Figure 2. TECs were resistant to the anti-cancer drug paclitaxel. A: Sensitivity to the cytotoxic drug, paclitaxel, was determined by the MTS assay after 72 hours of exposure. TECs were more resistant to paclitaxel than NECs. *** $P<0.01$. B: MDR1 mRNA expression was measured by real-time PCR. The MDR1 mRNA expression level in TECs was significantly higher than that in NECs. ${ }^{* *} P<0.01$. C: The P-gp expression level in TECs was up-regulated compared with that in NECs. ${ }^{* * *} P<0.01$. D: Paclitaxel sensitivity under verapamil treatment was determined by the MTS assay after 72-hour exposure. TECs were resensitized to paclitaxel by verapamil. ${ }^{* * *} P<0.01$ versus TECs without verapamil. E: The YB-1 expression level in NECs and TECs was analyzed under low and high magnification. The broken line indicates the nuclear area. YB-1 accumulation in TEC nuclei was greater compared with that in control NEC nuclei. Scale bar $=10 \mu \mathrm{m}$. F: The brightness value of YB-1 in the nucleus was quantified using ImageJ software. ${ }^{*} P<0.05$

expression level was higher in TECs than in NECs $(P<$ 0.01 , Figure $2 \mathrm{C}$ ). Furthermore, to determine whether paclitaxel resistance was due to MDR1/P-gp, we treated TECs with the P-gp inhibitor, verapamil, and confirmed that TECs were resensitized to paclitaxel by verapamil at $50 \mu \mathrm{mol} / \mathrm{L}$ (Figure 2D). Verapamil treatment was not cytotoxic to NECs or TECs at $50 \mu \mathrm{mol} / \mathrm{L}$ (see Supplemental Figure S1 at $h$ ttp://ajp.amjpathol.org). We then analyzed the localization of YB-1, which is a transcription factor of the MDR1 gene. Nuclear localization of YB-1 predicts drug resistance in some tumors. ${ }^{30-32}$ Nuclear expression of YB-1 was hardly detected in NECs, whereas nuclear accumulation of YB-1 was detected in TECs by immunocytochemical staining using confocal microscopy (Figure $2 \mathrm{E})$. A quantitative analysis revealed that nuclear expression of YB-1 increased significantly in TECs $(P<0.05$, Figure 2F). These results suggest that MDR1/P-gp upregulation may be a mechanism of drug resistance in TECs and that nuclear translocation of YB-1, which was 
A

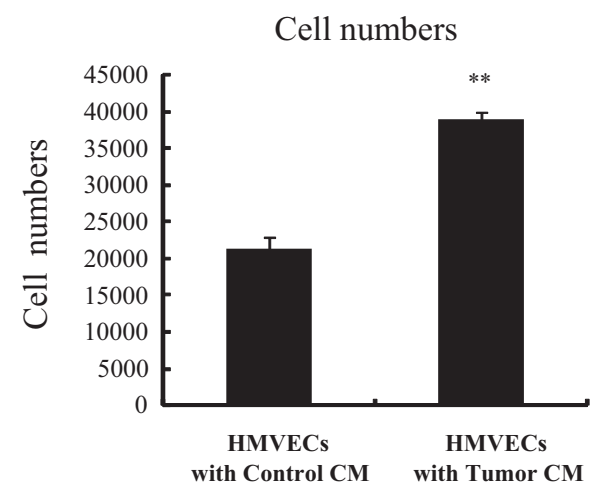

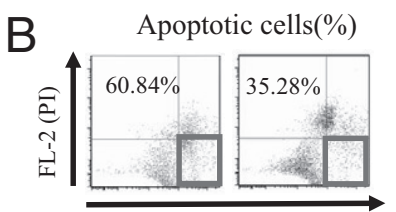

FL-1 (Annexin V)

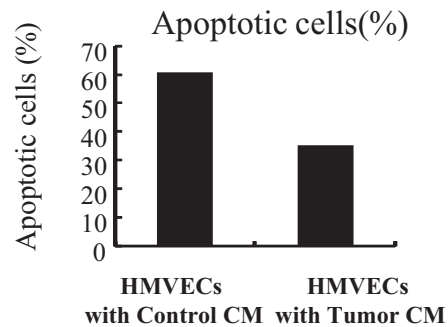

Dead cells $(\%)$

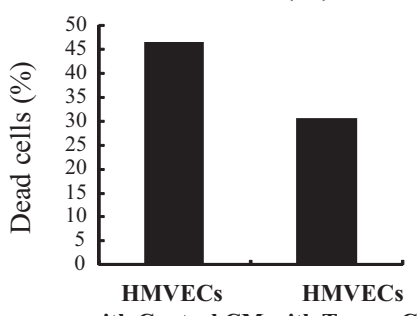

Figure 3. Tumor CM stimulated HMVEC proliferation and inhibited apoptosis. A: After HMVECs were cultured under their respective conditions for 5 days, cell numbers were counted after 48 hours of culture in each CM. Tumor CM significantly stimulated HMVEC proliferation. ${ }^{* * *} P<0.01$. B: Tumor CM enhanced resistance to serum starvation. HMVECs were cultured under their respective conditions for 5 days and starved for 24 hours in serum-free medium. The apoptotic cell number was determined by flow cytometry with annexin V-FLUOS and propidium iodide (PI). The apoptotic and dead cell numbers significantly decreased in tumor CM-treated HMVECs than in HMVECs treated with control CM under a serum starvation condition.

observed in tumor cells, contributes to MDR1/P-gp upregulation in TECs.

\section{Tumor CM Stimulates Human NEC Proliferation and Enhances Resistance to Serum Starvation}

CM was collected from tumor cells and human NECs; HMVECs were used to analyze the effects of tumor cell factors on the drug-resistant EC phenotypes. HMVECs were cultured with or without tumor $\mathrm{CM}$. Controls were treated with HMVEC CM collected after culturing HMVECs in $10 \%$ MEM. All HMVECs were treated for 5 days under each condition. To determine whether HMVEC CM was cytotoxic or cytostatic, we counted the dead cells after each medium treatment. HMVEC CM did not increase the number of dead HMVECs compared with EC medium (see Supplemental Figure S2 at http://ajp.amjpathol.org), indicating that HMVEC viability is not affected by culture in HMVEC CM. HMVEC proliferation was significantly higher in tumor $\mathrm{CM}$ than in control $\mathrm{CM}(P<0.01$, Figure $3 \mathrm{~A})$. In addition, apoptotic and dead cells from HMVEC cultures under serum and growth factor-free conditions were analyzed by FACS. The number of apoptotic and dead cells in tumor CM decreased significantly compared with that in the control (Figure 3B), suggesting that tumor CM confers resistance to serum starvation in HMVECs within 5 days.

\section{Tumor CM Induces MDR1 Up-Regulation and Nuclear Translocation of YB-1 in HMVECs}

To evaluate the effect of tumor CM on HMVEC sensitivity to anticancer drugs, we used real-time PCR for analyzing the MDR1 mRNA expression levels under the respective conditions. The MDR1 mRNA expression levels were twofold higher in HMVECs exposed to tumor CM for 5 days than those in control CM $(P<0.01)$. Furthermore, the MDR1 mRNA expression levels in HMVECs were elevated even after a single day of tumor CM treatment $(P<$ 0.01 , Figure 4A).
We then analyzed the localization of YB-1 in HMVECs after $\mathrm{CM}$ treatment. Nuclear expression of $\mathrm{YB}-1$ was hardly detected in the control, whereas nuclear accumulation of YB-1 was detected in HMVECs after 1 day of tumor CM treatment (Figure 4B). To confirm nuclear localization of $\mathrm{YB}-1$ in HMVECs after CM treatment, the extracted HMVEC protein was separated into cytoplasmic and nuclear fractions. We confirmed that the nuclear and cytoplasmic extracts were pure in each fraction using the cytoplasmic protein, $\beta$-tubulin, and the nuclear protein, hnRNP. YB-1 in each fraction was detected by using Western blot analysis. The amount of YB-1 in the nuclear fraction from tumor CM-treated HMVECs was significantly higher than that in the fraction from control HMVECs $(P<0.01$, Figure $4 C)$, suggesting that nuclear translocation of YB-1 contributes to MDR1 mRNA upregulation through tumor $\mathrm{CM}$ treatment in HMVECs.

\section{Tumor CM Induces Anticancer Drug Resistance in HMVECS}

We analyzed the sensitivity of tumor CM-treated HMVECs to the anticancer drug paclitaxel. Because paclitaxel is exported by P-gp, we surmised that drug sensitivity may be altered by tumor CM treatment. HMVECs were treated with respective $\mathrm{CM}$ for 5 days, followed by paclitaxel treatment for 48 hours. Paclitaxel-induced cell apoptosis was analyzed by FACS. The apoptotic cell number increased in a concentration-dependent manner with paclitaxel treatment. However, the apoptotic cell number in tumor CM-treated HMVECs was less than that in the control ( $P<0.05$, Figure 4D). To determine whether paclitaxel resistance was due to MDR1/P-gp, we treated HMVECs with the P-gp inhibitor verapamil (Figure 4E). The number of paclitaxel-induced apoptotic cells was analyzed with or without verapamil ( $50 \mu \mathrm{mol} / \mathrm{L})$ by FACS. Verapamil treatment was not cytotoxic to HMVECs at 50 $\mu \mathrm{mol} / \mathrm{L}$, and it resensitized HMVECs to paclitaxel even under tumor $\mathrm{CM}$ treatment $(P<0.01$, Figure $4 \mathrm{E})$, sug- 

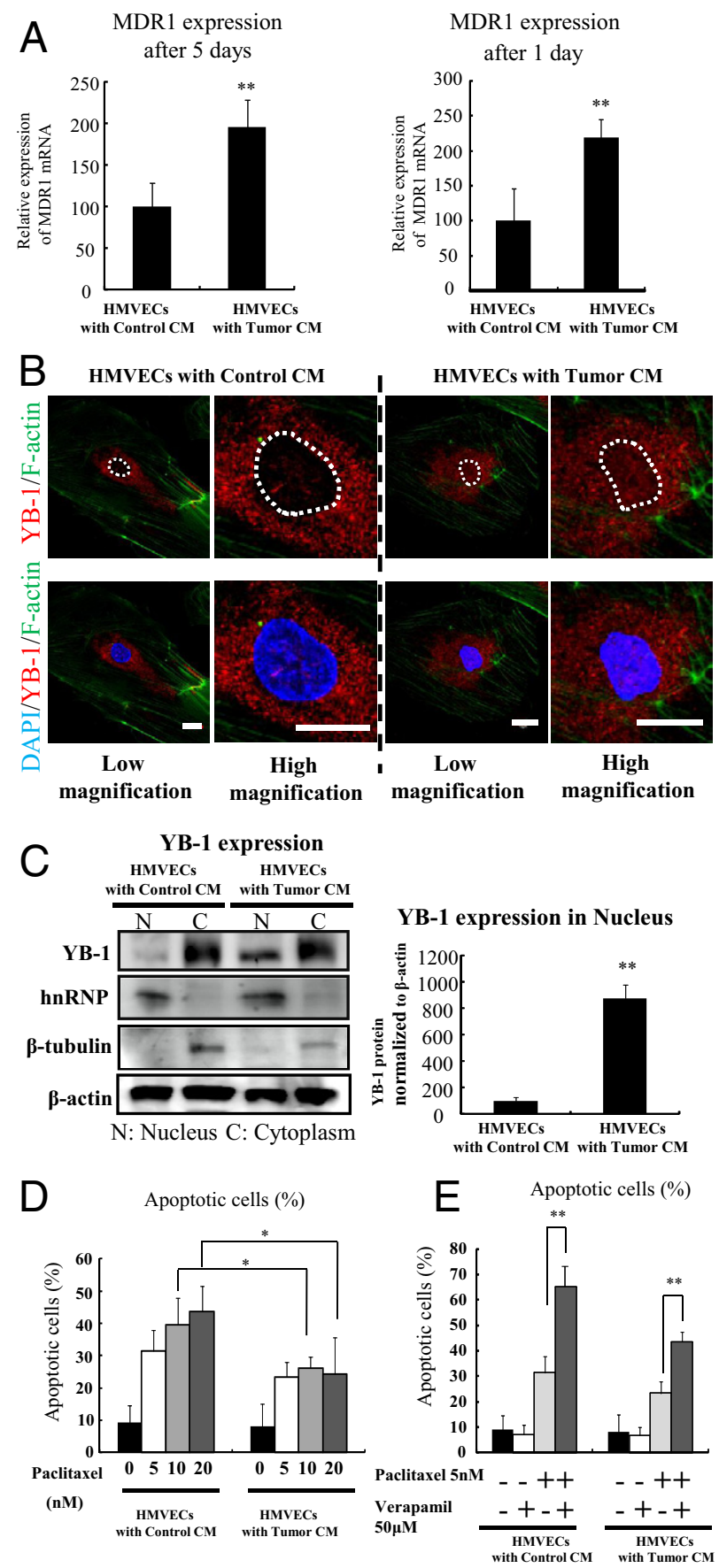

Figure 4. Tumor CM up-regulated MDR1 mRNA expression and YB-1 expression in HMVEC nuclei. A: HMVECs were cultured for 1 or 5 days in CM, and the MDR1 mRNA expression level was measured by real-time PCR. After 1- or 5-day tumor CM treatment, MDR1 mRNA expression in HMVECs was significantly up-regulated compared with that in the control. ${ }^{* *} P<0.01$. B: The YB-1 expression level in HMVECs cultured in control and tumor CM is shown under low and high magnification. The broken line shows the nuclear area. After 1 day of culture in tumor CM, YB-1 accumulation was greater in HMVEC nuclei than in control HMVECs. Scale bar $=20 \mu \mathrm{m}$. C: HMVECs were separated into cytoplasmic and nuclear fractions. The cell fractionation accuracy was confirmed by immunoblotting using the cytoplasmic protein, $\beta$-tubulin, and the nuclear protein, hnRNP. The amounts of YB-1 in the nuclear fraction from tumor CM-treated HMVECs were much higher than those in the fraction from control HMVECs. ${ }^{* *} P<0.01$. D: Tumor CM-treated HMVECs acquired paclitaxel resistance. The apoptotic cell number, as measured by FACS analysis with annexin $\mathrm{V}$ and propidium iodide, increased in a concentration-dependent manner. ${ }^{*} P<0.05$. E: Verapamil was not cytotoxic to HMVECs at $50 \mu \mathrm{mol} / \mathrm{L}$. The apoptotic cell number in HMVECs was restored by verapamil under each CM treatment condition. ${ }^{* * *} P<0.01$. gesting that MDR1/P-gp up-regulation is a mechanism of tumor CM-induced paclitaxel resistance in HMVECs.

\section{Akt Is Activated by Tumor CM, and Tumor CM- Induced MDR1 Up-Regulation Is Blocked by a PI3K Inhibitor in HMVECS}

Because the MDR1 mRNA expression levels are regulated by $\mathrm{YB}-1^{33}$ or microRNA, ${ }^{34}$ we hypothesized that MDR1 mRNA up-regulation may be caused by soluble factors, such as growth factors, cytokines, or microRNA, in tumor CM. The MDR1 mRNA expression levels did not change on exposure to HMVEC CM. In addition, resistance was not induced by CM from human melanocytes (melanocyte CM; see Supplemental Figure S3, A and B, at http://ajp.amjpathol.org). Thus, it was assumed that the factors responsible for MDR1 up-regulation and paclitaxel resistance may be tumor specific and contained in tumor CM. We analyzed MDR1 mRNA expression using preheated tumor $\mathrm{CM}$ to determine the factors in tumor $\mathrm{CM}$ that caused drug resistance in HMVECs. MDR1 mRNA expression did not change on treating HMVECs with preheated CM (Figure 5A), suggesting that proteins, such as cytokines or growth factors, in tumor CM may be responsible for MDR1 mRNA up-regulation in HMVECs. Akt activation was greater in tumor CM-treated HMVECs than in the control $(P<0.01$, Figure 5B). However, tumor $\mathrm{CM}$ did not elevate the MDR1 mRNA expression level when HMVECs were treated with the PI3K inhibitor, LY294002 (Figure 5C). These results suggest that Akt activation may be a mechanism of MDR1 mRNA upregulation by tumor $\mathrm{CM}$.

\section{VEGFR Kinase Inhibitor Blocks Tumor CM-Induced MDR1 mRNA Up-Regulation}

We compared the cytokine levels released from control and tumor cells by cytokine array analysis. Higher levels of several cytokines were observed in tumor CM than in control CM. Among these, the VEGF level in tumor CM was significantly higher than that in control CM (data not shown). ELISA also revealed that tumor CM contained significantly higher VEGF levels than control CM $(P<$ 0.01 , Figure 6A). Furthermore, VEGFR2 was phosphorylated and Akt was activated by tumor CM. However, the VEGFR kinase inhibitor, Ki8751, blocked Akt and VEGFR2 activation, even under tumor CM treatment (Figure $6 \mathrm{~B}$ ). To investigate the relationship between VEGF and MDR1 mRNA up-regulation, HMVECs were treated with Ki8751. Tumor CM did not increase the MDR1 mRNA expression level when HMVECs were treated with Ki8751 (Figure 6C). In summary, the results suggest that VEGF in tumor CM up-regulated the MDR1 mRNA expression level via the PI3K-Akt pathway.

\section{Discussion}

In this study, we report several new findings. i) TECs were more resistant to the anticancer drug paclitaxel after nuclear translocation of YB-1 and MDR1/P-gp up-regulation 

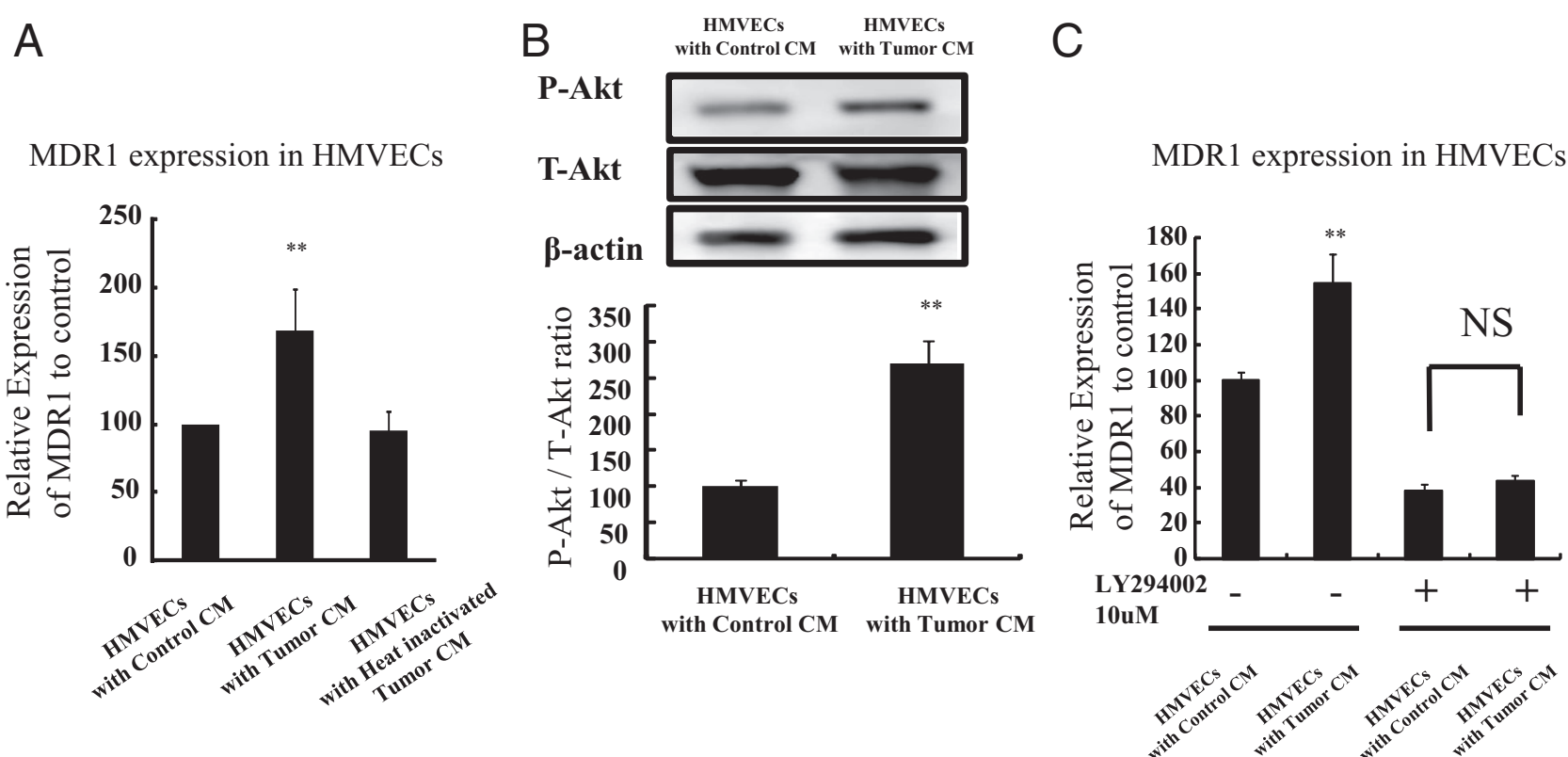

Figure 5. Tumor CM-induced MDR1 mRNA up-regulation in HMVECs was blocked by heat inactivation of tumor CM and LY294002. A: The MDR1 mRNA expression level was evaluated using tumor $\mathrm{CM}$ and heat-inactivated $\left(95^{\circ} \mathrm{C}\right.$ for 1 hour before use) tumor $\mathrm{CM}$. $\mathrm{HMVECs}$ were treated with $\mathrm{CM}$ for 1 day, and the MDR1 mRNA expression level was measured by real-time PCR. The MDR1 mRNA level did not change with exposure to heat-inactivated tumor CM. **ik $<0.01$. B: Akt was activated by tumor $\mathrm{CM}$, whereas the total Akt level remained unchanged. ${ }^{* * *} P<0.01$. The phosphorylated Akt (P-Akt) level was normalized to the total Akt (T-Akt) level and analyzed by scanning densitometry using ImageJ software. C: HMVECs were treated with LY294002 and each CM for 1 day. The MDR1 mRNA expression level was measured by real-time PCR. LY294002 inhibited tumor CM-induced MDR1 up-regulation. ${ }^{* *} P<0.01$.

compared with NECs. ii) Tumor CM stimulated cell proliferation in HMVECs (human NECs) and conferred resistance to serum starvation. iii) The MDR1 mRNA expression levels in HMVECs were up-regulated by tumor CM. The MDR1 transcription factor YB-1 was translocated into the nucleus, and HMVECs acquired paclitaxel resistance on tumor CM treatment. iv) Akt and VEGFR2 were activated in HMVECs by tumor CM. The PI3K-Akt inhibitor, LY294002, and the VEGFR kinase inhibitor, Ki8751, blocked tumor CM-induced MDR1 up-regulation, suggesting that MDR1 up-regulation via Akt activation by VEGF secreted from tumor cells may be one of the mechanisms of acquisition of drug resistance by TECs (Figure
7). We observed that TECs isolated from melanomas were more resistant to paclitaxel, suggesting that even ECs can acquire drug resistance in the tumor microenvironment, contrary to the previous concept that TECs are genetically stable and do not develop drug resistance. Regarding the previous concept, low-dose anti-angiogenic chemotherapy or metronomic chemotherapy has been developed to target TECs that do not acquire drug resistance. Several studies ${ }^{35,36}$ have shown an inhibitory effect of metronomic therapy using mouse tumor models. Paclitaxel is often used in these studies, and a range of its dose is from 10 to $20 \mathrm{nmol} / \mathrm{L}$. However, recent studies $^{37-40}$ report that drug resistance develops to even this

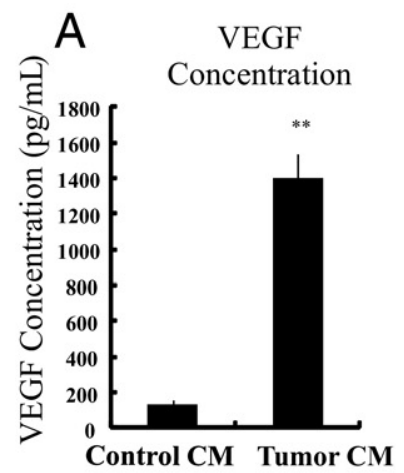

B

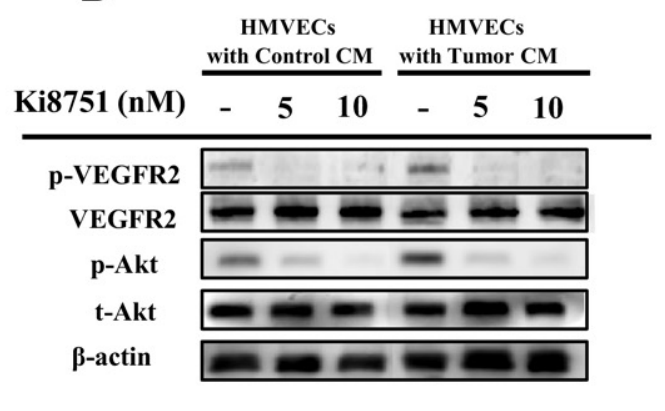

C

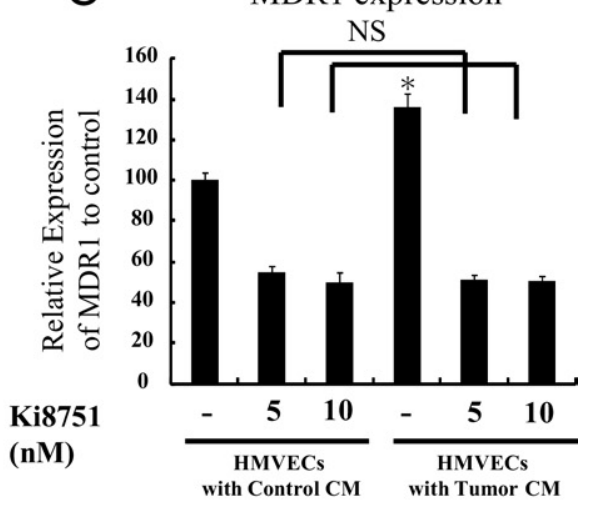

Figure 6. Tumor CM contained a high level of VEGF, and tumor CM-induced MDR1 mRNA up-regulation was blocked by a VEGFR kinase inhibitor. A: VEGF concentrations in CM were analyzed using ELISA and normalized by cell number per well. The VEGF level in tumor CM was higher than that in control CM. ** $P<$ 0.01. B: VEGFR2 was phosphorylated and Akt was activated by tumor CM. Ki8751 blocked Akt and VEGFR2 activation under tumor CM treatment. p, phosphorylated; t, total. C: HMVECs were treated with Ki8751 and each CM for 1 day. The MDR1 mRNA expression levels were measured by real-time PCR. Ki8751 inhibited tumor CM-induced MDR1 up-regulation. ${ }^{*} P<0.05$. NS, not significant. 


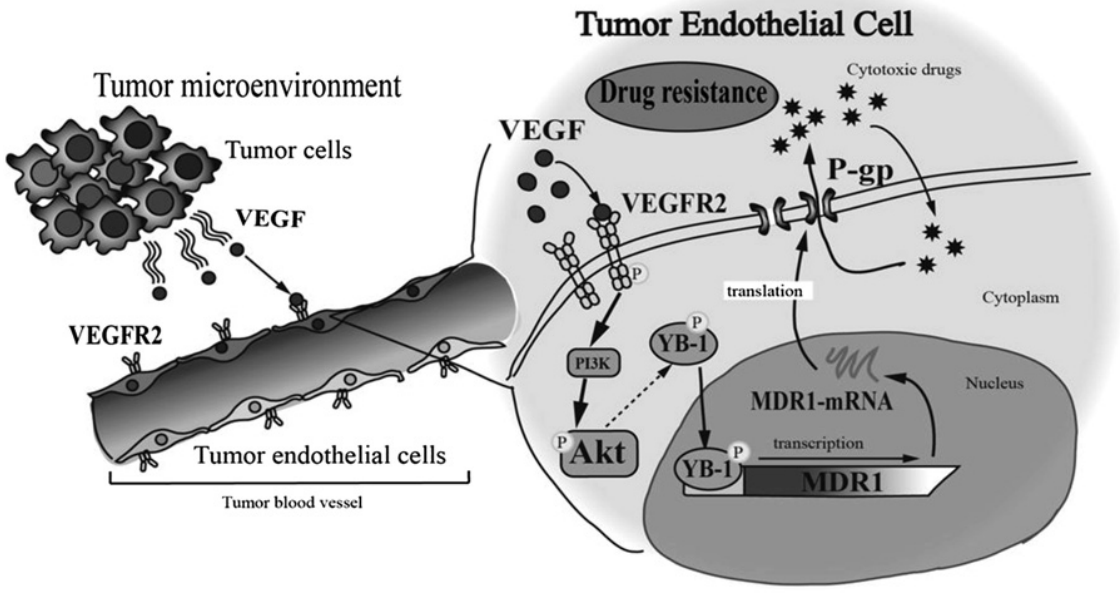

Figure 7. Possible mechanism of TEC drug resistance. TECs may acquire drug resistance through MDR1 mRNA up-regulation and nuclear translocation of YB-1 via Akt activation, caused by VEGF secreted from tumor cells in the tumor microenvironment. anti-angiogenic therapy. In our study, the inhibitory concentration of $50 \%$ of paclitaxel was $11 \mathrm{nmol} / \mathrm{L}$ in NECs and $39 \mathrm{nmol} / \mathrm{L}$ in TECs, showing that TECs are resistant to paclitaxel. Taken together, it was suggested that the dose used in low-dose metronomic paclitaxel may be effective for NECs but may not be effective anymore in TECs that have acquired drug resistance in the tumor microenvironment. These findings suggested that drug resistance against long-term anti-angiogenic chemotherapy may occur because of TEC resistance.

Many molecules participate in the drug-resistance mechanism. P-gp, which is encoded by the MDR1 gene, is a transmembrane glycoprotein that belongs to the ATPbinding cassette superfamily and functions as a multidrug transporter. Thus, MDR1/P-gp plays a major role in drug resistance. ${ }^{41}$ P-gp overexpression causes resistance to several anti-cancer drugs. ${ }^{42-44}$ Paclitaxel is a substrate transported by P-gp that is used together with an anti-angiogenic drug in treating several types of carcinomas. ${ }^{45,46}$ The transcriptional factor YB-1 is a multifunctional protein that participates in the transcriptional regulation of MDR1 mRNA, drug resistance, cell growth, and survival in tumor cells. ${ }^{33,47}$ Many studies ${ }^{30,32,48}$ have shown that YB-1 is highly expressed in various solid tumors, such as those in breast, lung, colon, and ovarian cancers. It was recently reported that YB-1 is highly expressed in tumor vessels compared with normal vessels. ${ }^{49}$ However, the mechanism of expression remains unknown.

In this study, we observed that mouse TECs were resistant to paclitaxel by nuclear translocation of $\mathrm{YB}-1$ and MDR1/P-gp up-regulation. We, therefore, surmised that TECs may acquire drug resistance in the tumor microenvironment. To analyze P-gp expression in human tumor blood vessels in vivo, we performed immunofluorescent double staining with anti-CD31 and anti-P-gp antibodies in the same frozen sections of human renal tumors and normal kidney tissues. P-gp was strongly expressed in tumor blood vessels but was hardly expressed in normal blood vessels, thereby suggesting that $\mathrm{P}$-gp was up-regulated in human and mouse TECs in vivo (see Supplemental Figure S4 at http://ajp.amjpathol.org).
Thus, we speculated that TECs acquire drug-resistance characteristics through the effects of tumor-derived factors. In fact, cross talk between tumor cells and stromal cells is important for tumor progression or acceleration of tumor malignancy. ${ }^{50}$ However, the mechanism by which TECs are affected by tumor-derived factors remains unclear.

To determine the mechanism of drug resistance in TECs, we analyzed the effect of tumor-derived factors on NECs using tumor CM. Tumor CM stimulated HMVEC proliferation and conferred resistance to serum starvation, suggesting that a factor from tumor cells could change HMVEC characteristics, even in a period as short as 5 days. Surprisingly, MDR1 mRNA was up-regulated from day 1 of tumor $\mathrm{CM}$ treatment. We observed that tumor $\mathrm{CM}$ induced nuclear translocation of $\mathrm{YB}-1$ in HMVECs, suggesting that MDR1 mRNA up-regulation was induced by nuclear translocation of YB-1 and that drug resistance occurred in HMVECs through tumor CM, similar to that observed in tumor cells. Similarly, tumor CM up-regulated MDR1 expression and caused an antiapoptotic phenotype in mouse NECs, as shown in HMVECs (see Supplemental Figure S5 at http://ajp.amjpathol.org), suggesting that the effects of tumor-derived factors may cause drug resistance in both human and mouse NECs.

Furthermore, MDR1 mRNA expression was up-regulated and sensitivity to the cytotoxic drug paclitaxel was lowered in HMVECs by tumor CM. However, these phenotypic changes were abolished when HMVECs were recultured in a tumor CM-free condition (EGM2-MV; data not shown), indicating a reversible change. In contrast, TECs showed stable MDR1 mRNA up-regulation, suggesting that an additional mechanism may be responsible for the resistance of TECs. We assumed that TECs may be affected by tumor cell factors in vivo and also by factors from other tumor stromal cells or hypoxia. In addition, the time course may be another factor. TECs were more influenced by the tumor microenvironment than the tumor CM-treated HMVECs because TECs were grown in vivo for 4 to 5 weeks. Paclitaxel sensitivity was restored by the P-gp inhibitor verapamil. However, even verapamil did not restore the apoptotic cell number to that observed 
in the control, suggesting that tumor $\mathrm{CM}$-induced drug resistance is, at least in part, due to MDR1/P-gp upregulation. Moreover, other factors, such as anti-apoptotic gene up-regulation or activation of cell survival pathways, may also account for this acquired phenotype. Growth factors released from tumor and stromal cells, such as VEGF, basic fibroblast growth factor, and EGF receptor ligands, are anti-apoptotic survival factors that may affect ECs in tumor tissues. ${ }^{51,52}$ To determine the contribution of proteins present in tumor CM, we analyzed the MDR1 mRNA expression levels in HMVECs using heat-inactivated tumor CM. The MDR1 mRNA levels did not change when HMVECs were treated with preheated tumor CM, suggesting that proteins, such as cytokines or growth factors, from tumor cells may cause MDR1 mRNA up-regulation and drug resistance in HMVECs. On observing that the VEGF levels in tumor $\mathrm{CM}$ were much higher than those in HMVEC CM, we analyzed Akt phosphorylation after tumor CM treatment. Akt was activated in HMVECs by tumor CM. Because Akt is a well-known survival factor, we assumed that Akt activation is a mechanism of drug resistance. Recent studies ${ }^{53-55}$ have shown a correlation between Akt activation and P-gp in cancer cells. Akt activation causes YB-1 serine 102 phosphorylation, resulting in nuclear translocation. ${ }^{56}$ We observed that the PI3K inhibitor, LY294002, blocked tumor CM-induced MDR1 up-regulation. Therefore, we assumed that Akt activation by tumor $\mathrm{CM}$ is a mechanism of paclitaxel resistance. Another melanoma (A375) CM also induced MDR1 mRNA up-regulation, whereas normal melanocyte CM did not. The VEGF levels in tumor CM were significantly higher than those in control or melanocyte CM (see Supplemental Figure S6 at $h t t p: / / a j p$. amjpathol.org). The VEGFR kinase inhibitor, Ki8751, blocked tumor CM-induced MDR1 up-regulation, suggesting that VEGF in malignant tumor CM may cause the acquired drug resistance. In conclusion, we demonstrate, for the first time to our knowledge, that TECs are resistant to paclitaxel through MDR1 mRNA upregulation and that NECs can acquire drug resistance through MDR1 mRNA up-regulation and nuclear translocation of YB-1 via Akt activation, caused by VEGF secreted from tumor cells.

\section{Acknowledgments}

We thank Dr. Isaiah J. Fidler for providing the A375SM supermetastatic human malignant melanoma cell line and Dr. Kazuyuki Yamamoto, Dr. Takahiro Osawa, Dr. Hitomi Omura, Dr. Chisaho Torii, and Yuko Suzuki for their technical assistance with the experiments.

\section{References}

1. Folkman J: Angiogenesis in cancer, vascular, rheumatoid and other disease. Nat Med 1995, 1:27-31

2. Folkman J: Role of angiogenesis in tumor growth and metastasis. Semin Oncol 2002, 29:15-18

3. Auerbach R, Akhtar N, Lewis RL, Shinners BL: Angiogenesis assays: problems and pitfalls. Cancer Metastasis Rev 2000, 19:167-172
4. Kerbel RS, Yu J, Tran J, Man S, Viloria-Petit A, Klement G, Coomber $\mathrm{BL}$, Rak J: Possible mechanisms of acquired resistance to antiangiogenic drugs: implications for the use of combination therapy approaches. Cancer Metastasis Rev 2001, 20:79-86

5. Browder T, Butterfield CE, Kraling BM, Shi B, Marshall B, O'Reilly MS, Folkman J: Antiangiogenic scheduling of chemotherapy improves efficacy against experimental drug-resistant cancer. Cancer Res 2000, 60:1878-1886

6. Man S, Bocci G, Francia G, Green SK, Jothy S, Hanahan D, Bohlen P, Hicklin DJ, Bergers G, Kerbel RS: Antitumor effects in mice of lowdose (metronomic) cyclophosphamide administered continuously through the drinking water. Cancer Res 2002, 62:2731-2735

7. Kato H, Ichinose $Y$, Ohta M, Hata E, Tsubota N, Tada H, Watanabe $Y$, Wada $H$, Tsuboi $M$, Hamajima $N$ : A randomized trial of adjuvant chemotherapy with uracil-tegafur for adenocarcinoma of the lung. N Engl J Med 2004, 350:1713-1721

8. Mehta RS, Jackson D, Schubbert T: Metronomic schedule of paclitaxel is effective in hormone receptor-positive and hormone receptornegative breast cancer. J Clin Oncol 2009, 27:3067-3068; author reply 3068-3069

9. Jain RK: Molecular regulation of vessel maturation. Nat Med 2003, 9:685-693

10. McDonald DM, Baluk P: Significance of blood vessel leakiness in cancer. Cancer Res 2002, 62:5381-5385

11. Morikawa S, Baluk P, Kaidoh T, Haskell A, Jain RK, McDonald DM: Abnormalities in pericytes on blood vessels and endothelial sprouts in tumors. Am J Pathol 2002, 160:985-1000

12. St Croix B, Rago C, Velculescu V, Traverso G, Romans KE, Montgomery E, Lal A, Riggins GJ, Lengauer C, Vogelstein B, Kinzler KW: Genes expressed in human tumor endothelium. Science 2000, 289 1197-1202

13. Lu C, Bonome T, Li Y, Kamat AA, Han LY, Schmandt R, Coleman RL, Gershenson DM, Jaffe RB, Birrer MJ, Sood AK: Gene alterations identified by expression profiling in tumor-associated endothelial cells from invasive ovarian carcinoma. Cancer Res 2007, 67:17571768

14. Seaman S, Stevens J, Yang MY, Logsdon D, Graff-Cherry C, St Croix $\mathrm{B}$ : Genes that distinguish physiological and pathological angiogenesis. Cancer Cell 2007, 11:539-554

15. Hida K, Hida Y, Amin DN, Flint AF, Panigrahy D, Morton CC, Klagsbrun M: Tumor-associated endothelial cells with cytogenetic abnormalities. Cancer Res 2004, 64:8249-8255

16. Hida K, Klagsbrun M: A new perspective on tumor endothelial cells: unexpected chromosome and centrosome abnormalities. Cancer Res 2005, 65:2507-2510

17. Amin DN, Hida K, Bielenberg DR, Klagsbrun M: Tumor endothelial cells express epidermal growth factor receptor (EGFR) but not ErbB3 and are responsive to EGF and to EGFR kinase inhibitors. Cancer Res 2006, 66:2173-2180

18. Tsuchiya K, Hida K, Hida Y, Muraki C, Ohga N, Akino T, Kondo T, Miseki T, Nakagawa K, Shindoh M, Harabayashi T, Shinohara N, Nonomura K, Kobayashi M: Adrenomedullin antagonist suppresses tumor formation in renal cell carcinoma through inhibitory effects on tumor endothelial cells and endothelial progenitor mobilization. Int $J$ Oncol 2010, 36:1379-1386

19. Matsuda K, Ohga N, Hida Y, Muraki C, Tsuchiya K, Kurosu T, Akino T, Shih SC, Totsuka Y, Klagsbrun M, Shindoh M, Hida K: Isolated tumor endothelial cells maintain specific character during long-term culture. Biochem Biophys Res Commun 2010, 394:947-954

20. Ohga N, Hida K, Hida Y, Muraki C, Tsuchiya K, Matsuda K, Ohiro Y, Totsuka $Y$, Shindoh M: Inhibitory effects of epigallocatechin-3 gallate, a polyphenol in green tea, on tumor-associated endothelial cells and endothelial progenitor cells. Cancer Sci 2009, 100:1963-1970

21. Akino T, Hida K, Hida Y, Tsuchiya K, Freedman D, Muraki C, Ohga N, Matsuda K, Akiyama K, Harabayashi T, Shinohara N, Nonomura K, Klagsbrun M, Shindoh M: Cytogenetic abnormalities of tumor-associated endothelial cells in human malignant tumors. Am J Pathol 2009, 175:2657-2667

22. Streubel B, Chott A, Huber D, Exner M, Jager U, Wagner O, Schwarzinger I: Lymphoma-specific genetic aberrations in microvascular endothelial cells in B-cell lymphomas. N Engl J Med 2004, 351:250259 
23. Bussolati B, Deambrosis I, Russo S, Deregibus MC, Camussi G: Altered angiogenesis and survival in human tumor-derived endothelial cells. FASEB J 2003, 17:1159-1161

24. Grange C, Bussolati B, Bruno S, Fonsato V, Sapino A, Camussi G: Isolation and characterization of human breast tumor-derived endothelial cells. Oncol Rep 2006, 15:381-386

25. Xiong YQ, Sun HC, Zhang W, Zhu XD, Zhuang PY, Zhang JB, Wang L, Wu WZ, Qin LX, Tang ZY: Human hepatocellular carcinoma tumorderived endothelial cells manifest increased angiogenesis capability and drug resistance compared with normal endothelial cells. Clin Cancer Res 2009, 15:4838-4846

26. Kozlowski JM, Hart IR, Fidler IJ, Hanna N: A human melanoma line heterogeneous with respect to metastatic capacity in athymic nude mice. J Natl Cancer Inst 1984, 72:913-917

27. Hida K, Hida Y, Shindoh M: Understanding tumor endothelial cell abnormalities to develop ideal anti-angiogenic therapies. Cancer Sci 2008, 99:459-466

28. Arbiser JL, Larsson $H$, Claesson-Welsh L, Bai X, LaMontagne $\mathrm{K}$, Weiss SW, Soker S, Flynn E, Brown LF: Overexpression of VEGF 121 in immortalized endothelial cells causes conversion to slowly growing angiosarcoma and high level expression of the VEGF receptors VEGFR-1 and VEGFR-2 in vivo. Am J Pathol 2000, 156:1469-1476

29. Kurosu T, Ohga N, Hida Y, Maishi N, Akiyama K, Kakuguchi W, Kuroshima T, Kondo M, Akino T, Totsuka Y, Shindoh M, Higashino F Hida K: HuR keeps an angiogenic switch on by stabilising mRNA of VEGF and COX-2 in tumour endothelium. Br J Cancer 2011, 104:819829

30. Janz M, Harbeck N, Dettmar P, Berger U, Schmidt A, Jurchott K, Schmitt M, Royer HD: Y-box factor YB-1 predicts drug resistance and patient outcome in breast cancer independent of clinically relevant tumor biologic factors HER2, UPA and PAl-1. Int J Cancer 2002, 97:278-282

31. Gimenez-Bonafe P, Fedoruk MN, Whitmore TG, Akbari M, Ralph JL, Ettinger S, Gleave ME, Nelson CC: YB-1 is upregulated during prostate cancer tumor progression and increases P-glycoprotein activity. Prostate 2004, 59:337-349

32. Huang X, Ushijima K, Komai K, Takemoto Y, Motoshima S, Kamura T, Kohno K: Co-expression of $Y$ box-binding protein-1 and P-glycoprotein as a prognostic marker for survival in epithelial ovarian cancer. Gynecol Oncol 2004, 93:287-291

33. Kuwano M, Uchiumi T, Hayakawa H, Ono M, Wada M, Izumi H, Kohno $\mathrm{K}$ : The basic and clinical implications of $\mathrm{ABC}$ transporters: $\mathrm{Y}$-boxbinding protein-1 (YB-1) and angiogenesis-related factors in human malignancies. Cancer Sci 2003, 94:9-14

34. Zhu H, Wu H, Liu X, Evans BR, Medina DJ, Liu CG, Yang JM: Role of MicroRNA miR-27a and miR-451 in the regulation of MDR1/P-glycoprotein expression in human cancer cells. Biochem Pharmacol 2008 , 76:582-588

35. Patel N, Chatterjee SK, Vrbanac V, Chung I, Mu CJ, Olsen RR, Waghorne C, Zetter BR: Rescue of paclitaxel sensitivity by repression of Prohibitin1 in drug-resistant cancer cells. Proc Natl Acad Sci U S A 2010, 107:2503-2508

36. Mi YJ, Liang YJ, Huang HB, Zhao HY, Wu CP, Wang F, Tao LY, Zhang CZ, Dai CL, Tiwari AK, Ma XX, To KK, Ambudkar SV, Chen ZS, Fu LW: Apatinib (YN968D1) reverses multidrug resistance by inhibiting the efflux function of multiple ATP-binding cassette transporters. Cancer Res 2010, 70:7981-7991

37. Kesari S, Schiff D, Doherty L, Gigas DC, Batchelor TT, Muzikansky A, O'Neill A, Drappatz J, Chen-Plotkin AS, Ramakrishna N, Weiss SE, Levy B, Bradshaw J, Kracher J, Laforme A, Black PM, Folkman J, Kieran M, Wen PY: Phase II study of metronomic chemotherapy for recurrent malignant gliomas in adults. Neuro Oncol 2007, 9:354-363

38. Krzyzanowska MK, Tannock IF, Lockwood G, Knox J, Moore M, Bjarnason GA: A phase II trial of continuous low-dose oral cyclophosphamide and celecoxib in patients with renal cell carcinoma. Cancer Chemother Pharmacol 2007, 60:135-141

39. Bhatt RS, Merchan J, Parker R, Wu HK, Zhang L, Seery V, Heymach JV, Atkins MB, McDermott D, Sukhatme VP: A phase 2 pilot trial of low-dose, continuous infusion, or "metronomic" paclitaxel and oral celecoxib in patients with metastatic melanoma. Cancer 2010, 116:1751-1756

40. Pasquier E, Kavallaris M, Andre N: Metronomic chemotherapy: new rationale for new directions. Nat Rev Clin Oncol 2010, 7:455-465

41. Sarkadi B, Homolya L, Szakacs G, Varadi A: Human multidrug resistance $A B C B$ and $A B C G$ transporters: participation in a chemoimmunity defense system. Physiol Rev 2006, 86:1179-1236

42. Lasagna N, Fantappie O, Solazzo M, Morbidelli L, Marchetti S, Cipriani G, Ziche M, Mazzanti R: Hepatocyte growth factor and inducible nitric oxide synthase are involved in multidrug resistance-induced angiogenesis in hepatocellular carcinoma cell lines. Cancer Res 2006, 66:2673-2682

43. Fidler IJ, Kim SJ, Langley RR: The role of the organ microenvironment in the biology and therapy of cancer metastasis. J Cell Biochem 2007, 101:927-936

44. Perez-Sayans M, Somoza-Martin JM, Barros-Angueira F, Diz PG, Rey JM, Garcia-Garcia A: Multidrug resistance in oral squamous cell carcinoma: the role of vacuolar ATPases. Cancer Lett 2010, 295:135143

45. Sandler A, Gray R, Perry MC, Brahmer J, Schiller JH, Dowlati A, Lilenbaum R, Johnson DH: Paclitaxel-carboplatin alone or with bevacizumab for non-small-cell lung cancer. N Engl J Med 2006, 355: $2542-2550$

46. Miller K, Wang M, Gralow J, Dickler M, Cobleigh M, Perez EA, Shenkier T, Cella D, Davidson NE: Paclitaxel plus bevacizumab versus paclitaxel alone for metastatic breast cancer. N Engl J Med 2007, 357:2666-2676

47. Swamynathan SK, Nambiar A, Guntaka RV: Role of single-stranded DNA regions and $Y$-box proteins in transcriptional regulation of viral and cellular genes. FASEB J 1998, 12:515-522

48. Mantwill K, Kohler-Vargas N, Bernshausen A, Bieler A, Lage H, Kaszubiak A, Surowiak P, Dravits T, Treiber U, Hartung R, Gansbacher B, Holm PS: Inhibition of the multidrug-resistant phenotype by targeting YB-1 with a conditionally oncolytic adenovirus: implications for combinatorial treatment regimen with chemotherapeutic agents. Cancer Res 2006, 66:7195-7202

49. Takahashi M, Shimajiri S, Izumi H, Hirano G, Kashiwagi E, Yasuniwa Y, Wu Y, Han B, Akiyama M, Nishizawa S, Sasaguri Y, Kohno K: Y-box binding protein-1 is a novel molecular target for tumor vessels. Cancer Sci 2010, 101:1367-1373

50. Karnoub AE, Dash AB, Vo AP, Sullivan A, Brooks MW, Bell GW, Richardson AL, Polyak K, Tubo R, Weinberg RA: Mesenchymal stem cells within tumour stroma promote breast cancer metastasis. Nature 2007, 449:557-563

51. Vogelstein B, Kinzler KW: Cancer genes and the pathways they control. Nat Med 2004, 10:789-799

52. Alavi AS, Acevedo L, Min W, Cheresh DA: Chemoresistance of endothelial cells induced by basic fibroblast growth factor depends on Raf-1-mediated inhibition of the proapoptotic kinase, ASK1. Cancer Res 2007, 67:2766-2772

53. Barancik M, Bohacova V, Sedlak J, Sulova Z, Breier A: LY294,002, a specific inhibitor of PI3K/Akt kinase pathway, antagonizes P-glycoprotein-mediated multidrug resistance. Eur J Pharm Sci 2006, 29: $426-434$

54. Choi BH, Kim CG, Lim Y, Shin SY, Lee YH: Curcumin down-regulates the multidrug-resistance mdr1b gene by inhibiting the PI3K/Akt/NF kappa B pathway. Cancer Lett 2008, 259:111-118

55. Zhang Y, Qu X, Hu X, Yang X, Hou K, Teng Y, Zhang J, Sada K, Liu $Y$ : Reversal of P-glycoprotein-mediated multi-drug resistance by the E3 ubiquitin ligase Cbl-b in human gastric adenocarcinoma cells. J Pathol 2009, 218:248-255

56. Sutherland BW, Kucab J, Wu J, Lee C, Cheang MC, Yorida E, Turbin D, Dedhar S, Nelson C, Pollak M, Leighton Grimes H, Miller K, Badve S, Huntsman D, Blake-Gilks C, Chen M, Pallen CJ, Dunn SE: Akt phosphorylates the $\mathrm{Y}$-box binding protein 1 at Ser102 located in the cold shock domain and affects the anchorage-independent growth of breast cancer cells. Oncogene 2005, 24:4281-4292 